\title{
Queer Categories: Queer(y)ing the identification 'older lesbian, gay and/or bisexual (LGB) adults' and its implications for organisational research, policy and practice
}

Dr Andrew King, University of Surrey

\section{Accepted final version to be published in Gender, Work and Organization}

\begin{abstract}
In recent years there has been a growth in organisational discourse concerning the lives of older lesbian, gay and/or bisexual (LGB) adults, which has started to address the serious omission and invisibility of this group of people in research, policy making, and service provision. Whilst this development is welcomed, it inevitably draws attention to the identification 'older LGB adults' on which it is based. Using insights from Queer Theory, in addition to the sociological perspectives of ethnomethodology and conversation analysis, this article troubles or 'queers' such identifications. It does this, not only theoretically, but empirically, by conducting a membership categorization analysis (MCA) of some data emanating from a small organisational scoping study of older LGB adults. The ramifications of this for organisational research, policy making and practice are considered in the conclusion.
\end{abstract}

\section{Introduction}

The relationship between ageing and sexuality is contentious and older people are often represented as either being sexually inactive, dysfunctional or not having a sexual identity (Gott and Hinchliff, 2003; Lee, 2007). Aside from ageism, this representation also obscures the lives of those who are largely defined by their sexuality: older lesbian, gay and/or bisexual (LGB) people ${ }^{\mathrm{i}}$. 
Recently, a once noted 'queer absence' (Cronin, 2004) concerning older ${ }^{\mathrm{ii}}$ LGB people in organisational research, policy and practice has started to be addressed (Stonewall Cymru and Triangle Wales, 2006; Davies et al., 2006; Communities Scotland, 2005; Knocker, 2006; Opening Doors in Thanet, 2003; Taylor, 2012). Key issues identified are how to improve services, such as those in housing and health and social care, for this group of older people and, to an extent, how there are differential experiences amongst older LGB people (Knocker, 2012). While this literature is to be welcomed, shining a light on questions of marginality and inequality amongst sexual minority communities, in much organisational discourse the identification older LGB people emerges as a largely taken-for-granted identity and as such it posits sexuality as a master status through which other identities are framed. This stands in contrast to academic perspectives that have questioned such identifications and which point towards difference, diversity and complexity. The aim of this article is to consider this tension: between what we know about older LGB people from organisational discourse, what we know about identity categories from queer theory and sociology and how empirical data obtained from a study commissioned by an organisation to explore the lives of older LGB people can be re-used to illustrate the need to queer categories ${ }^{\mathrm{iii}}$.

The article begins by outlining what organisational discourse tells us about older LGB people before considering how this identification is troubled by queer theory, particularly the work of Judith Butler, in addition to ethnomethodology and conversation analysis. After a brief discussion of the methodology of a small, scoping study conducted by the author and a colleague for a local government authority concerning its older LGB community, the article gives a detailed membership categorisation analysis (MCA) of the account of one gay man to exemplify the queering of categories. In the concluding section the consequences of such queer(y)ing are discussed, including the ramifications for organisational policy and practice. 


\section{Identifying Older LGB Adults in organisational discourse}

Using demographic and organisational data, Age UK (2002), a leading UK charity dedicated to the well-being of older people, estimates that one in fifteen of its service users will be lesbian, gay or bisexual. Meanwhile, Almack et al (2010) cite other sources (e.g Department of Trade and Industry Women and Equality Unit, 2003; Price, 2005) that suggest that 5-7 per cent of the UK population are lesbian, gay and/or bisexual and that 545,000 to 872,000 of those are over sixty-five.

Over the past decade in the UK, older LGB adults have been the subjects of organisational research, policy and practice initiatives aimed at understanding their lives and improving services for them. Drivers for this have come from equality legislation, policy initiatives and community activism (King, 2013). Organisational research itself suggests that older LGB people do experience later life differently from their heterosexual peers. For instance, a recent survey by Stonewall (Guasp, 2011), a leading UK-based LGB rights and advocacy organisation, suggested older LGB people are more likely to be living alone, less likely to have dependent children, more likely to rely on public services and express more concerns about social isolation than their heterosexual peers. Such findings are supported, to an extent, by research from other third sector organisations, which also emphasise that older LGB people are subject to a range of discriminations that need to be addressed by policy makers and practitioners within housing, health and social care and leisure services (Age UK, 2011; Knocker, 2006; 2012; Carr and Ross, 2013). Indeed, Age UK has successfully operated a project, 'Opening Doors', which offers a befriending service for older LGB people, together with an information service and training programme for organisations seeking to address their practices for this community. 
Such organisational discourses are closely aligned with research emanating from academia, particularly in the fields of gerontology, social work and, to an extent, sociology. Here studies have focused heavily on the effects of institutional heteronormativity and heterosexism on older LGB people's lives and the need to develop inclusive practices and policies in fields such as health care (Keogh et al., 2004; Cant, 2005) and residential care (Tolley and Ranzijn, 2006; Stein et al., 2010).

Whilst this combined organisational discourse sheds light on a previously marginalised and disempowered group of older people, Heaphy (2007: 194) has suggested that there is an epistemological problem here:

a problem that stems from the conceptual significance afforded sexual identity as the key determining factor of lesbian and gay experience. A more sophisticated understanding is required of social constraints and possibilities as they relate to non-heterosexual living and ageing.

In effect Heaphy (2007) has argued for a more nuanced approach to account for sexuality as always framed in relation to other aspects of identity, such as age, gender and social class; to question the notion of older LGB adults, in the singular, focusing on individuals who are intersected by a range of differences. Although Heaphy's primary concern is with understanding the relationship between sexuality, ageing and social change, he implicitly indicates the need to trouble older LGB identifications. In essence, whilst not eschewing the significance of the aforementioned studies for developing affirmative policies relevant to people who identify as older LGB, such identifications may occlude the complex production and resistance of identity categorisations and consequently inequalities of power that they elide. It is here, I believe, that insights from queer theory and other sociological approaches are important. 


\section{Queering older LGB adults}

Queer theory takes the deconstruction of categories of identity and knowledge as its central analytic task (Green, 2007; Seidman, 1995; Fuss, 1991) arguing that whether these are considered the product of an essential biology or a process of social construction, they obscure differential experiences and re-affirm existing inequalities. Sullivan (2003: vi) argues that to queer is 'to make strange, to frustrate, to counteract, to delegitimise, to camp up heteronormative knowledge and institutions'. Hence, queer theory demonstrates that identities are unstable, fluidic fictions that are the effects of regimes of power/knowledge, which order bodies and desires (Jagose, 1996; Seidman, 1996; 1997). Moreover, sexual identity categories are regulatory, since heteronormativity is a discourse that normalises and governs the identities that it brings into being (Fuss, 1991).

The bringing into being of categories of identity is something that Judith Butler has discussed throughout her work. She asserts that discursive categories are performative; that is, they constitute what they name. Butler's famous example is how biomedical (and heteronormative) conceptions of gender produce a subject position from which subjectivity is constituted and the same process can be applied to sexuality:

[gender] is thus not the product of choice, but the forcible citation of a norm, one whose complex historicity is indissociable from relations of discipline, regulation, punishment. Indeed, there is no 'one' who takes on a gender norm. On the contrary, this citation of the gender norm is necessary in order to qualify as a 'one', to become viable as a 'one', where subject-formation is dependent on the prior operation of legitimating gender norms (Butler, 1993: 232)

Furthermore, these performative acts bring subjects into being, such that actively trying to resist identification can be problematic. Indeed, contemplating the problem of writing within and through sexual identity categories, Butler states: 
Identity categories tend to be instruments of regulatory regimes, whether as the normalising categories of oppressive structures or as rallying points for a liberatory contestation of that very oppression. This is not to say that I will not appear at political occasions under the sign of a lesbian, but I would like to have it permanently unclear what precisely that sign means. (Butler, 1991: 13-14)

Butler has been criticised for ignoring materiality and employing an approach that is overly linguistic and deterministic (McNay, 2004; Benhabib, 1995; Hood-Williams and Cealey-Harrison, 1998), although this is something she has vociferously denied and sought to clarify (Butler, 1999; 2004). However, the value of her work is, I believe, the demonstration that identities are inherently political; to elaborate on their performativity is to establish 'as political the very terms through which identity is articulated' (Butler 1990: 148).

Applying this queer approach to older LGB adults would mean questioning the approach taken in much of the organisational literature noted earlier, wherein equality is a fundamental goal, which is regarded as attainable through negotiation and conflict resolution around identity categories. From a queer perspective, this approach pays too little attention to the disciplinary power of heteronormativity to regulate selves. Moving from such a position, what is required is the examination of how older LGB identities are constituted in relation to and draw upon heteronormative presumptions. However, whilst theoretically useful, both queer theory and the work of Butler tend to be conceptual and their empirical grounding is consequently more problematic for those engaged in empirical research. Hence, an approach is needed that can undertake such a practice.

It has been noted by others that a queer methodology needs to be developed to examine how people accomplish, transform and transgress gender and sexual identities, amongst others, in specific settings, including organisational settings (McIlvenny, 2002a; Speer and Potter, 2002; Speer, 2005; Fenstermaker and West, 2002; Moloney and Fenstermaker, 2002; 2002b). The suggestion made by these writers, which I wish to follow, 
draws on other sociological approaches that also radically trouble and show the contested, constructed nature of identities, but in situ: ethnomethodology and conversation analysis.

Ethnomethodology (EM) examines the methods people use to make sense of their social worlds and order their understandings of it (Garfinkel, 1967). This is achieved primarily through their use of accounts: descriptions of something or someone that are tied to the situation in which they are uttered/written (Heritage, 1984). Accounts are both indexical, tied to the context of their use, and yet draw on people's background expectations about the social world.

EM has previously been used to investigate questions of sexual and gender identity (Crawford, 2000; Fenstermaker and West, 2002; Hicks, 2008) as well as examine organisational settings (Button and Sharrock, 2009; Lynch, 1993; Rawls, 2008). Overall, EM focuses on how people 'do' identities in such settings, for specific purposes, since it contends that disconnecting these from their context of production is problematic because it imposes an interpretation or theory on something that has already been formulated by social actors.

The question of how identities are constructed in settings, through talk, is a central concern of conversation analysis (CA), which was developed by Harvey Sacks, who was himself influenced by ethnomethodology (Silverman, 1998). CA has become a broad research program that focuses on various aspects of naturally occurring talk, or talk-ininteraction, including: turn-taking; overlaps and pauses; and categories and their associated attributes and activities (Silverman, 1998). Although both EM and CA have been accused of being overly descriptive and concerned with the minutiae of social interactions, as well as politically naïve in ways that fails to account for wider issues of structure and power, both can provide a radical reflexivity that questions the taken-for-granted through examining its 
constitution (Coser, 1975; Hilbert, 1990; Pollner, 1991; Billig, 1999; Kitzinger, 2000; Speer, 2002). Indeed, Sacks and others have suggested that much research and here we could include organisational research, works on the basis of applying 'undescribed categories', such as age, gender, sexuality, class, ethnicity etc, as resources to analyse social problems, producing 'facts' about these (Zimmerman and Pollner, 1970/1990; Sacks, 1963/1990). Instead, these authors contend research should be attuned to how people construct the aforementioned 'undescribed categories' themselves.

Membership Categorisation Analysis (MCA) is a form of CA that explores the 'situated and reflexive use of categories in everyday and institutional interaction' (Benwell and Stokoe, 2006: 38). Categories can be people, places and events, whilst predicates are actions or characteristics that are bound to categories. Categories are arranged into devices (MCDs) also called collections, although a single category can belong to many: for example, the categories 'mum' and 'dad' can belong to the devices 'parents', 'family' and 'gender'. It is how these are used, in particular contexts that enable such meanings to be fixed, for that instance. Moreover, MCA shows how cultural understandings are carried by discourse and are reproduced and transformed in their use (Baker, 2000). For instance MCA studies have shown how gender categories are used in complex and situated ways that both transgress and reproduce existing gender norms in a university setting (Stokoe, 2004) and how categories can also be combined to establish moral and behavioural precedents (Jayyusi, 1984). It can, therefore, be used to analyse specific instances of the categorisation of people, places and events, the micro-politics of interactions, but it also is attuned to detailing how these iterations link to wider discursive norms and practices. 
MCA can, however, become too concerned with the substance of categories, neglecting their sequential organisation (Housley and Fitzgerald, 2002; Schegloff, 2007) and ignoring how the meanings of categories and predicates develop and change during the course of an account. Without attending to this level of analysis, it is argued, MCA is not very different from thematic and grounded forms of analysis that are more traditional in qualitative research. To avoid this, it is imperative to consider the sequential positioning and reorientation of categories and predicates as they are used throughout an account (Watson, 1997; Stokoe, 2003).

How does this relate to the constitution of older LGB adults in organisational discourse? The approach I am suggesting would mean treating this set of identity categories as accomplishments, exploring how they are constituted by people themselves (including researchers, employers, service providers) in specific settings and how they draw on wider discourses, or in MCA terms, collections, related to sexuality and age, amongst any others made relevant by people engaged in the social action. Both queer theory and EM/CA/MCA emphasise the contingency and instability of identity, although approaching it in different ways. Hence, the approach I am arguing for links the more macro concerns with power and the troubling of identity categories addressed by queer theory, but exploring these in actual instances of situated social action through MCA.

In summary, this section of the article has noted that organisational discourses have produced 'older LGB adults' as a group of people adhering to a particular set of identity categories and subject positions from which their experiences can be read and interpreted. Whilst this is in many ways useful and important, enabling social, institutional and legal policies to be developed, as a sociologist I believe that drawing on queer theory, 
$\mathrm{EM} / \mathrm{CA} / \mathrm{MCA}$ is important to explore categorisation work as it takes place in organisational contexts. Hence, using this theoretical and methodological approach, I am arguing for a troubling of the categorisation 'older LGB adult' in action; to explore how it is always contextually produced, yet saturated with wider social and cultural norms. The remainder of this article will undertake such an analysis and consider its ramifications.

\section{Methodology}

This article draws on data that I gathered with a colleague as part of a project examining the lives, experiences and service needs of older LGB people who lived or worked in an area of London, UK, commissioned by a local government authority as part of its on-going equality work. This research sampled 22 older LGB adults who were recruited via newspaper adverts, flyers in public settings, including those in the LGB community, and online LGB forums. In total, ten gay men, eleven lesbians and one bisexual man participated. All participants identified as White British, except one gay man who identified as Mixed White/Black African Caribbean.

Participants were given pseudonyms and their accounts were analysed using a threestep MCA (King, 2010). This involved: identifying key membership categories, devices and predicates (CDPs) within the sample; mapping the sequence of these CDPs within each account and across the sample; and identifying how certain CDPs were treated as anomalies or disruptions by the co-participants in the talk that required some form of explanation or 'repair' work. Other discursive features related to identity work, such as deploying special forms of knowledge, 'collection K' (Sacks, 1995) and 'contrast statements' (Smith, 1978) were also identified. In accordance with MCA principles, other social identities were viewed as relevant, but only if made relevant by members in the talk-in-interaction. However, to 
contextualise the analysis, some biographical details have been added and some CA conventions are used in the extracts, although I have not utilised the full CA transcription conventions developed by Gail Jefferson (see Psathas, 1995) as the extent to which these are necessary for this MCA is debateable. The data extracts outlined below do, however, indicate pauses in speech by timings in seconds that are placed in brackets, for instance (1.0) would indicate a pause of one second. A very short but audible pause would be indicated thus (.).

For the purposes of this article I want to re-analyse an account provided by one of the scoping study participants using the approach I have already outlined. This is not because this account is necessarily typical of all those produced in the sample. I have chosen this account, however, because it shows how identity categories and predicates associated with them are used to create subject positions related to sexuality and age, indicated by the interviewer's categorisation work, which are then deftly and skilfully reworked by the participant himself to produce an identification that is both inclusive enough for him to be a participant in the research, yet distinct enough not to be easily categorised as an 'older LGB adult'. Furthermore, the use of a specific, critical case has been used effectively and persuasively in the work of Butler and ethnomethodology (Butler, 1993; Garfinkel, 1967). I contend my case illustrates how, through membership categorisation work, identifications concerning age and sexuality are locally produced and contested, whilst drawing on wider discourses.

\section{Making trouble in organisational settings}

The extracts outlined below come from an interview conducted with Ernest who was 73 years old when interviewed. The interview took place in a health related setting and commenced, like others, with a question concerning sexual identity. Thus, the interviewer's question makes the collection of categories related to sexuality directly relevant to the subsequent talk. 
Int: we all use different terms to describe our sexuality so it would be helpful for me if you could tell me how you describe your sexual identity?

Ernest: Right (0.1) er well (.) I feel it's a very important issue (.) well it is for me I'm a gay man (.) but my gayness is not (.) what I would call my primary characteristic (.) er my primary characteristic is that I'm male (.) and er (.) I would do everything that I would expect an ordinary male to do except that when it comes to sex then I'm going to prefer to have sex with other men (.) but that's the only way I consider myself to be gay

In answering the interviewer's question, Ernest does invoke one of the categories associated with the collection, sexuality: 'gay man'. Instead, Ernest indicates that his understanding of this identification is more complex and is related to predicates associated with 'doing' rather than 'being'. As evident, Ernest reworks the categorisation 'gay man' into a predicate, 'gayness' and consequently makes his membership of the category more problematic. In effect, he has not affirmed 'I'm a gay man', adopting a liberationist sexuality identity category, in an unproblematic way.

Subsequently, Ernest emphasises the other collection made relevant by the categorisation 'gay male' that of gender, claiming that 'male' is his 'primary characteristic'. So gender here appears to have precedence over sexuality for his identity. Again, Ernest emphasises a distinction around 'doing': what distinguishes Ernest from being an 'ordinary male' is, in his view, something he 'does': he has 'sex with other men'.

It appears that Ernest's categorisation work here draws on and reinforces heteronormativity - heterosexual men, men who don't have sex with other men, are 'ordinary'; conversely, being 'gay' is not ordinary, it is unusual/queer. This interpretation would seem to be confirmed when Ernest continues to provide an account of why 'gay' is not his 'primary characteristic': 
I've never lived erm (.) I've always been around other gay people but I've never lived in an exclusively gay community I've never been in an exclusively gay relationship although I've had quite a few fairly long-term gay relationships (.) but er (.) I wouldn't consider anything like a civil partnership or anything in a formalised way (.) I have been married but that was purely for erm immigration purposes while I lived briefly in America (0.3) and that didn't succeed at all (laughs)(0.5) it wasn't a very rewarding experience

Here Ernest lists a series of predicates and categories that he associates with being 'gay' and in invoking them in such a way further explains why his own membership of this category is problematic: membership of a gay community, an exclusively gay relationship and civil partnerships are not relevant to him.

There is a sense, therefore, in which Ernest is emphasising contemporary forms of homonormativity (Rosenfeld, 2009; Duggan, 2003), whilst simultaneously distancing himself from them. Previous research has indicated that older gay men like Ernest, who grew up in an era before homosexuality was decriminalised, are more likely to attempt to 'pass' as heterosexual than those who grew up after decriminalisation (Rosenfeld, 2002; Knauer, 2011; 2009). However, exploring Ernest's own categorisation work further shows, I think, that this is more complex.

Ernest explains that his friendship circle has always included gay people and he has had 'long-term gay relationships'. Moreover, he suggests that his attachment to the heteronormative institution 'marriage' was both instrumental and unrewarding; a suggestion that is further emphasised by the use of laughter. In effect, Ernest subtly and skilfully situates himself as 'gay', but not typically gay. Whilst this could be read as heteronormative, as a rejection of homosexuality because it is stigmatised, it also troubles this identification since Ernest is actively rejecting existing categorisations and situating himself as different. Arguably, what might be the result of a lifetime of passing could also be a more subtle 
practice of transgression. Having spent a lifetime of avoiding being categorised (and in some cases pathologised), this indicates how Ernest views his sexuality: as something he does rather than something he is, ontologically. To simply label Ernest as 'gay', which could well happen in organisational research and practice or for that matter a MSM (man who has sex with other men) would miss this more complex understanding.

A similar complex identification appears in a latter section of Ernest's interview when age is made relevant by the interviewer's question. In the account that follows Ernest refuses to let himself be categorised as 'older':

Int: what about service provision for older people do you think

Ernest: There again I have very rarely got myself involved (.) and not classifying myself as gay I don't classify myself as er old (0.1) I just don't think in terms of age [...] so that's [his voluntary work] brought me much more in to focus the needs of older people and what older people talk about er (.) which is mainly sitting around chatting about the old days (laughs) it's not really my scene but you know you listen (.) and you try and be as helpful as you can

Ernest's clearly rejects membership of the category 'old'. Yet instead of simply ending the account at this point, and by implication his inclusion in the organisational research itself, he attempts to speak to this categorisation by discussing his voluntary work. This, he suggests, has made him 'think' about what older people need and about their behaviours: their talk, 'chatting about the old days'. He also dissociates himself from their 'scene', itself an interesting attribution since it implicitly references the 'gay scene', something he has already made clear is not relevant to him. Furthermore, his suggestion that his role was to 'listen' and 'be helpful' again dissociates him from membership of the category 'older person' through actions: they talk, he listens. 
Ernest's rejection of an aged subject position invoked by the interviewer could suggest he adheres to normative notions of later life, as dependent and increasingly infantilised (Hockey and James, 1993). After all, Ernest could be categorised as 'older' according to normative models of ageing, including that utilised by the researchers. Yet again, however, he skilfully positions himself as being able to speak to the category introduced by the interviewer, but also to imbue it with difference. In this respect, his laughter can be heard as ironic; as co-opting the interviewer who has already categorised him as 'older' into his way of viewing himself (Jefferson, 1979). To simply categorise Ernest as 'an older gay man' would therefore be problematic. His own categorisation work creates trouble for such identifications.

To reiterate, although Ernest's account was different from others in the study, it also had similarities: a desire not to be easily classified; to be similar yet different from other lesbian, gay and/or bisexual people; to reorient the general category 'older'. In the following section I consider the wider ramifications of this close reading of membership categorisation work for research, as well as wider policy and practice.

\section{Discussion and conclusion}

This article has suggested that there has been a growth of organisational discourse over recent years, which constitutes older LGB people as a sexual minority group who warrant special attention in terms of institutional research, policy and practice. This has been accompanied by policy-initiatives, training courses and community-led support networks. Whilst these are to be welcomed, since they shed light on and improve lives for people who have experienced stigmatisation, discrimination and victimisation, I have asserted throughout this article that a 
questioning or troubling of these sexual and indeed age identifications are necessary given insights emanating from the social sciences that questions stable identities.

The article has shown that analysing people's categorisations of themselves and others, of people and events, shows that the identification 'older LGB person' is not straightforward, indeed it needs to be queer(y)ed. Following queer theory, I have argued that such identity categories are regulatory: they shape and constrain the possibilities of existence, constituting subject positions, which can be fulfilled. Moreover, I have used EM/CA/MCA to ground these concerns and explore how identifications related to sexuality and age are worked up and worked out on specific occasions, for specific purposes. For as Baker (2000) has argued, categories and categorisation work are micro instances of wider discursive power structures. Indeed, categorising someone as an 'older LGB' person, for the purposes of organisational research, policy or practice is performative, it locates people in a subject position that they may, or may not, accept. In fact, it is not even a simplistic binary form of positioning of acceptance or denial: discursive practices are used to maintain membership, whilst at the same time expressing individuality and creating trouble for categories.

The implications of this are particularly consequential. Invoking or hailing people as an older LGB person, for instance in equality work or care home training manuals is both inclusive, but it is also exclusive. It is an appeal to sexual citizenship (Weeks, 2007), to be part of a collective, with rights and protections under the law. Yet it is also about fitting into place; moulding the self to certain ideals and ways of being and behaving (Richardson, 2004; Taylor, 2008). In this respect, Butler's conception of the queer subject is poignant; there is both agency and constraint or to paraphrase one of her aphorisms: one can appear under the 
sign 'older LGB adult', but it should be permanently unclear what precisely that sign signifies (original in Butler, 1991: 14).

Heteronormative and normative age conceptions of the 'other' remain: to be an older LGB person is to explicitly categorise oneself as not heterosexual and not young, whilst retaining the parameters of a heteronormative age order. As Cronin (2004: 109) has asserted in relation to normative models of ageing, such a model 'reinforces the normality of the reference group's experiences whilst minimising the differing social reality of groups who stand outside the socially constructed norm'; in this case, being categorised as an 'older LGB' person limits the possibilities for agency, it positions a person within a (hetero)normative matrix. It is unsurprising, therefore, that when such a performative categorisation takes place, as in the case of the interview with Ernest, it may be resisted. As noted earlier, this is especially pertinent to those who have been pathologised and stigmatised because of their sexual identification. Furthermore, despite laws and policies to deter ageism, being categorised as 'older' in an ageist culture that valorises youth (Hockey and James, 1993; 2003) is similarly constraining. To be an 'older LGB' adult is potentially, and in some situations, doubly problematic. Yet this article has also demonstrated how people use and transgress (hetero)normative models of sexuality and ageing to produce complex identifications of themselves.

All of this means that organisations need to consider the complex ways that people categorise themselves and how they make trouble for existing normative orders. Following Garfinkel (1967), we should not treat people as 'cultural dupes' who are in thrall to normative orders, considering instead how these both shape and are challenged by the everyday practices of identification people employ. This represents a first step to understanding the 
pervasiveness and instability of heteronorms, a grounded notion of the more abstract ideas expressed by queer theory. To ignore these everyday practices would, in my view, be to impose a sense of determinism on action and overshadow the complex micro-politics that they indicate.

Further research, within organisations, could examine these issues in more naturalistic settings. Research could, for example, look at how sexual orientation monitoring is actually accomplished in situ in a care home or health setting. It could explore how clients actively shape and resist such categorisations, although it is notable to see that some organisations have called for these to be used in a less disciplinary way, allowing clients to produce their own meanings (Opening Doors London and Age UK Camden, 2011). Alternatively, longitudinal research could explore identity work over a more extended period of time, avoiding the 'tick box' approach to equality noted by others (Monro, 2006). Overall, a more nuanced, questioning approach to the politics of identity amongst people grouped as 'older LGB adults' need to remain on organisational agendas.

\section{Acknowledgements}

The author would like to thank the three anonymous reviewers and the editors for their positive and supportive feedback. Additionally, the author would like to thank Mahamani Cronin who co-researched the study on which this article is based.

\section{References}

Age Concern. (2002) Issues Facing Older Lesbians, Gay Men and Bisexuals. Age UK. (2011) Supporting Older Lesbian, Gay, Bisexual and Transgender People: A Checklist for Social Care Providers. London: Age UK.

Almack K, Seymour J and Bellamy G. (2010) Exploring the Impact of Sexual Orientation on Experiences and Concerns about End of Life Care and on Bereavement for Lesbian, Gay and Bisexual Older People. Sociology 44: 908-924. 
Baker C. (2000) Locating Culture in Action: Membership Categorisation in Texts and Talk. In: Lee A and Poynton C (eds) Culture and Text: Discourse and Methodology in Social Research and Cultural Studies. St Leonards, NSW: Allen \& Unwin, 99-113.

Benhabib S. (1995) Feminism and Postmodernism. In: Benhabib S, Butler J, Cornell D, et al. (eds) Feminist Contentions. London: Routledge. p 17-34, 17-34.

Benwell B and Stokoe E. (2006) Discourse and Identity, Edinburgh: Edinburgh University Press.

Billig M. (1999) Whose Terms? Whose Ordinariness? Rhetoric and Ideology in Conversation Analysis. Discourse and Society 10: 543-558.

Butler J. (1991) Imitation and Gender Insubordination. In: Fuss D (ed) Inside/Out: Lesbian Theory/Gay Theories. London: Routledge, 13-31.

Butler J. (1993) Bodies that Matter: On the Discursive Limits of Sex, New York: Routledge.

Butler J. (1999) Performativity's Social Magic. In: Shusterman R (ed) Bourdieu: A Critical Reader. Oxford: Blackwell. p113-128, 113-128.

Butler J. (2004) Undoing Gender, London: Routledge.

Button G and Sharrock W. (2009) Studies of Work and the Workplace in HCI: Concepts and Techniques San Rafael, Calif: Morgan and Claypool.

Cant B. (2005) Exploring the Implications for Health Professionals of Men Coming Out as Gay in Healthcare Settings. Health and Social Care in the Community 14: 9-16.

Carr S and Ross P. (2013) Assessing Current and Future Housing and Support Options for Older LGB People. York: Joseph Rowntree Foundation.

Communities Scotland. (2005) Precis \#67: Housing and support needs of older lesbian, gay, bisexual and transgender (LGBT) people in Scotland. Edinburgh: Communities Scotland. Available from URL www.communitiesscotland.gov.uk/stellent/groups/public/documents/webpages/pubcs _008930.pdf (Date accessed 04/02/08).

Coser L. (1975) Two Methods in Search of a Substance: Presidential Address. American Sociological Review 40: 671-700.

Crawford M. (2000) A Reappraisal of Gender: An Ethnomethodological Approach: Editor's Introduction. Feminism \& Psychology 10: 7-10.

Cronin A. (2004) Sexuality in Gerontology: A Heteronormative Presence, A Queer Absence. In: Daatland SO and Biggs S (eds) Ageing and Diversity : Multiple pathways and cultural migrations. Bristol: Policy Press.

Davies M, Addis S, MacBride-Stewart S, et al. (2006) The Health, Social Care and Housing needs of Lesbian, Gay, Bisexual and Transgender older people: literature review. Cardiff: Centre for Health Sciences Research, Cardiff University. .

Department of Trade and Industry Women and Equality Unit. (2003) Civil Partnership: A Framework for the Legal Recognition of Same-Sex Couples. London: Department for Trade and Industry.

Duggan L. (2003) The Twilight of Equality? Neoliberalism, Cultural Politics and the Attack on American Democracy, Boston: Beacon Press.

Fenstermaker S and West C. (2002) Doing Gender, Doing Difference: Inequality, Power and Institutional Change. London: Routledge.

Fuss D. (1991) Inside/Out. In: Fuss D (ed) Inside/Out: Lesbian Theories, Gay Theories. London: Routledge, 1-10.

Garfinkel H. (1967) Studies in Ethnomethdology, Englewood Cliff, NJ.: Prentice Hall. 
Gott M and Hinchliff S. (2003) How important is sex in later life? The views of older people. Social Science \& Medicine 56: 1617-1628.

Green AI. (2007) Queer Theory and Sociology: Locating the Subject and the Self in Sexuality Studies. Sociological Theory 25: 26-45.

Guasp A. (2011) Lesbian, Gay and Bisexual People in Later Life. London: Stonewall.

Heaphy B. (2007) Sexualities, Gender and Ageing: Resources and Social Change. Current Sociology 55: 193-210.

Heritage J. (1984) Garfinkel and Ethnomethodology, Cambridge: Polity Press.

Hicks S. (2008) Thinking Through Sexuality. Journal of Social Work 8: 65-82.

Hilbert RA. (1990) Ethnomethodology and the Micro-Macro Order. American Sociological Review 55: 794-808.

Hockey J and James A. (1993) Growing up and Growing Old: Ageing and Dependency in the Life Course, London: Sage Publications.

Hockey J and James A. (2003) Social Identities Across the Lifecourse, Houndmills, Basingstoke: Palgrave MacMillan.

Hood-Williams J and Cealey-Harrison W. (1998) Trouble with Gender. The Sociological Review 46: 73-94.

Housley W and Fitzgerald R. (2002) The Reconsidered Model of Membership Categorization Analysis. Qualitative Research 2: 59-83.

Jagose A. (1996) Queer Theory. Australian Humanities Review: Available online http://www.lib.latrobe.edu.au/AHR/archive/Issue-Dec-1996/jagose.html (Accessed 1910/1904/1907).

Jayyusi L. (1984) Categorization and the Moral Order, Boston: Routledge and Kegan Paul.

Jefferson G. (1979) A Technique for Inviting Laughter and its Subsequent Acceptance/Declination. In: Psathas G (ed) Everyday Language: Studies in Ethnomethodology. London: Wiley. p79-96., 79-96.

Keogh P, Weatherburn P, Henderson L, et al. (2004) Doctoring Gay Men: Exploring the Contribution of General Practice. London: SIGMA Research. Available online at $<$ http://www.sigmaresearch.org.uk/downloads/report04d.pdf $>$ (Date accessed 25/11/08).

King A. (2010) Membership Matters: Applying Membership Categorisation Analysis (MCA) to Qualitative Data Using Computer Assisted Qualitative Data Analysis (CAQDAS) Software. International Journal of Social Research Methodology 13: 1-16.

King A. (2013) Prepare for Impact? Reflecting on Knowledge Exchange Work to Improve Services for Older LGBT People in Times of Austerity, in Social Policy and Society. Available at:

http://journals.cambridge.org/action/displayAbstract?fromPage=online \&aid=9076446 \&fulltextType=RA\&fileId=S1474746413000523.

Kitzinger C. (2000) Doing Feminist Conversation Analysis. Feminism \& Psychology 10: 163-193.

Knauer NJ. (2011) Gay and Lesbian Elders: History, Law and Identity Politics in the United States, Farnham: Ashgate.

Knocker S. (2006) The Whole of Me: Meeting the Needs of Older Lesbians, Gay Men and Bisexuals Living in Care Homes and Extra Care Housing. Age Concern. Available online at http://www.scie-socialcareonline.org.uk/profile.asp?guid=0b250fa8-c0e9493b-8c50-07f963114d32. 
Knocker S. (2012) Perspectives on Ageing: Lesbians, Gay Men and Bisexuals. York: Joseph Rountree Foundation.

Lee A. (2007) 'I can't ask that!' Promoting Discussion of Sexuality and Effective Health Service Interactions with Older Non-Heterosexual Men. In: Clarke K, Maltby T and Kennett P (eds) Social Policy Review 19: Analysis and Debate in Social Policy, 2007. Bristol: Policy Press. pp. 127-150., 127-150.

Lynch M. (1993) Scientific Practice and Ordinary Action: Ethnomethodology and Social Studies of Science Cambridge: Cambridge University Press.

McIlvenny P. (2002a) Critical Reflections on Performativity and the 'Un/Doing' of Gender and Sexuality in Talk. In: McIlvenny P (ed) Talking Gender and Sexuality. Philadelphia: John Benjamins. p111-149, 111-149.

McIlvenny P. (2002b) Introduction: Researching Talk, Gender and Sexuality. In: McIlvenny P (ed) Talking Gender and Sexuality. Philadelphia: John Benjamins. p1-47, 1-47.

McNay L. (2004) Agency and Experience: Gender as a Lived Relation. In: Adkins L and Skeggs B (eds) Feminism After Bourdieu. Oxford: Blackwell. p175-190, 175-190.

Moloney M and Fenstermaker S. (2002) Performance and Accomplishment: Reconciling Feminist Conceptions of Gender. In: Fenstermaker S and West C (eds) Doing Gender, Doing Difference: Inequality, Power and Institutional Change. New York: Routledge. p189-204, 189-204.

Monro S. (2006) Evaluating Local Government Equalities Work: The Case of Sexualities Initiatives in the UK. Local Government Studies 32: 19-39.

Opening Doors in Thanet. (2003) Equally Different: Report on the Situation of Older Lesbian, Gay, Bisexual and Transgendered People in Thanet, Kent. Available online at <http://www.casweb.org/polari/filestorage/index?folder_id=34791\&n_past_days=99999> (Date accessed 31/10/08).

Opening Doors London and Age UK Camden. (2011) Checklist for Social Care Organisations working with older Lesbian, Gay, Bisexual and Transgender People. available online at http://www.stonewall.org.uk/documents/older_lgbt_checklist_for_adult_social_care.p df (date accessed 03/01/14).

Pollner M. (1991) Left of Ethnomethodology: The Rise and Decline of Radical Reflexivity. American Sociological Review 56: 370-380.

Price E. (2005) All but Invisible: Older Gay Men and Lesbians. Nursing Older People 17: 16-18.

Psathas G. (1995) Conversation Analysis: The Study of Talk-in-Interaction, London: Sage.

Rawls AW. (2008) Harold Garfinkel, Ethnomethodology and Workplace Studies. Organization Studies 29: 701-732.

Richardson D. (2004) Locating Sexualities: From Here to Normality. Sexualities 9: 391-411.

Rosenfeld D. (2002) Identity Careers of Older Gay Men and Lesbians. In: Gubrium F and Holstein J (eds) Ways of Aging. Oxford: Blackwell, 160-181.

Rosenfeld D. (2009) Heteronormativity and Homonormativity as Practical and Moral Resources: The Case of Lesbian and Gay Elders. Gender and Society 23: 617-638.

Sacks H. (1963/1990) Sociological Description. In: Coulter J (ed) Ethnomethodological Sociology. Aldershot: Edward Elgar Publishing Limited. p79-85, 85-79.

Sacks H. (1995) Lectures on Conversation: Volumes 1\&2, Oxford: Blackwell.

Schegloff EA. (2007) A Tutorial on Membership Categorization. Journal of Pragmatics 39: 462-482. 
Seidman S. (1995) Deconstructing Queer Theory or the Undertheorization of the Social and the Ethical. In: Nicholson L and Seidman S (eds) Social Postmodernism: Beyond Identity Politics. Cambridge: Cambridge University Press. p116-141.

Seidman S. (1996) Introduction. In: Seidman S (ed) Queer Theory/Sociology. Oxford: Blackwell. p1-29, 1-29.

Seidman S. (1997) Difference Troubles: Queering Social Theory and Sexual Politics, Cambridge: Cambridge University Press.

Silverman D. (1998) Harvey Sacks: Social Science and Conversation Analysis, Oxford: Polity Press.

Smith D. (1978) K is Mentally Ill: The Anatomy of a Factual Account. Sociology 12: 23-53.

Speer SA. (2002) What Can Conversation Analysis Contribute To Feminist Methodology? Putting Reflexivity Into Practice. Discourse and Society 13: 783-803.

Speer SA. (2005) Gender Talk: Feminism, Discourse and Conversation Analysis, London: Routledge.

Speer SA and Potter J. (2002) From Performatives to Practices: Judith Butler, Discursive Psychology and the Management of Heterosexist Talk. In: McIlvenny P (ed) Talking Gender and Sexuality. Philadelphia: John Benjamins. p151-180, 151-180.

Stein GL, Beckerman NL and Sherman PA. (2010) Lesbian and Gay Elders and Long-Term Care: Indentifying the Unique Psychosocial Perspectives and Challlenges. Journal of Gerontological Social Work 53: 421-435.

Stokoe EH. (2003) Doing Gender, Doing Categorisation: Recent Developments in Language and Gender Research. International Sociolinguistics 2: 1-12.

Stokoe EH. (2004) Gender and Discourse, Gender and Categorization: Current Developments in Language and Gender Research. Qualitative Research in Psychology 1: 107-129.

Stonewall Cymru and Triangle Wales. (2006) The housing needs of lesbian, gay and bisexual (LGB) people in Wales. Cardiff: Welsh Assembly. Available from URL www.stonewallcymru.org.uk/documents/triangle_wale_report_engli.pdf (Date accessed 04/02/08).

Sullivan N. (2003) A Critical Introduction to Queer Theory, Edinburgh: Edinburgh University Press.

Taylor J. (2012) Working with older lesbian, gay and bisexual people: a guide for care and support services, London: Stonewall.

Taylor Y. (2008) 'That's Not Really My Scene': Working-Class Lesbians In (and Out of) Place. Sexualities 11: 523-546.

Tolley C and Ranzijn R. (2006) Heteronormativity Amongst Staff of Residential Care Facilities. Gay and Lesbian Issues and Psychology Review 2: 78-86.

Watson R. (1997) Some General Reflections on 'Categorization' and 'Sequence' in the Analysis of Conversation. In: Hester S and Eglin P (eds) Culture in Action: Studies in Membership Categorization Analysis. London: International Institute for Ethnomethodology and Conversation Analysis/University Press of America Inc. p49$76,49-76$.

Weeks J. (2007) The World We Have Won: The Remaking of Erotic and Intimate Life, London: Routledge.

Zimmerman DH and Pollner M. (1970/1990) The Everyday World as a Phenomenon. In: Coulter J (ed) Ethnomethodological Sociology. Aldershot: Edward Elgar Publishing Limited. p96-137, 96-137. 


\footnotetext{
${ }^{\mathrm{i}}$ Studies frequently make reference to LGBT people i.e. lesbian, gay bisexual and/or transgender and almost as frequently these pay scant attention to the lives of older trans people, particularly issues surrounding gender identity. I do not intend to replicate this glossing here and will focus on issues of sexuality, always mindful that trans people may define as lesbian, gay, bisexual, heterosexual, pansexual or asexual.

ii It is unclear when 'older' adulthood begins, but for the purposes of this paper and consistent with the gerontological literature, I am referring to adults over the age of fifty.

iii Some discussion and the data presented in this article have been excerpted from King, A and Cronin, A 'Queer Methods and Queer Practices: Re-examining the identities of older lesbian, gay, bisexual (OLGB) adults'. In: Browne K and Nash C (eds) Queer Methods and Methodologies (Farham: Ashgate/Gower 2010), pp.85-96 Copyright @2010
} 